\title{
Three Parallel Verses in the Buddhacarita and the Aśokāvadāna
}

\section{Kensuke OKAMOTO}

Aśvaghoșa's Buddhacarita (abbr. BC) ${ }^{1)}$ was composed in the 1 st or 2 nd century C.E. Moreover, Chapters 26-29 (the so-called Aśokāvadāna: abbr. AA) ${ }^{2)}$ of the Divyāvadāna were compiled around the 2 nd or 3 rd century C.E. The compilation dates of the two texts are close. Also, both these texts have a common new feature, previously unknown, namely they include an almost complete biography of the Buddha from his birth to the parinirvāna 3) . Therefore, we might expect these two texts to have a close relationship. In fact, Gawroński points out that BC and AA have one parallel verse, as well as, some passages in common $^{4)}$. However, there has been no further attempt to compare these texts.

Below, we examine three more verses ${ }^{5)}$ in $\mathrm{BC}_{\text {and }} \mathrm{AA}^{6)}$, which are parallel word for word. As a result, a great portion of the lost original Sanskrit texts of these verses in BC can be recovered from the Sanskrit texts of AA. We can also see a closer relationship between $\mathrm{BC}$ and $\mathrm{AA}$ than it has generally been assumed by previous scholars.

* The following Sanskrit texts are literally quoted from the Divyāvadāna of Cowell edition. Variants of Sanskrit texts are referred to in the notes. Solid underline (_ _ ) : words appearing only in BC; Dotted underline ( $\ldots$ ): words appearing only in AA; Wavy underline (_ ) : corresponding words but not identical.

【Parallel verse 1】
(a) 'phags pa mau rya (rgya'i CD) dpal des (de NP) skye dgu'i (dgur CD) phan don du //
(b) 'jig rten kun la mchod rten mtshan ma byed du bcug //
(c) gtum po mya ngan med nyid thob nas sa la ni //
(d) chos rgyal mya ngan med nyid las des(de CD) thob par gyur // [BC 28.64]

(A) àryamauryaśrīh ${ }^{7)}$ sa prajāāām hitāartham 
( 76 ) Three Parallel Verses in the Buddhacarita and the Aśokāvadāna (K. Окамото)

(B) kṛtsnam stūpān kārayām āsa lokam ${ }^{8)} /{ }^{9)}$

(C) candāáskatvam prāpya pūrvam prthivyām

(D) dharmāśokatvam karman̄ā tena lebhe // [AA 381.26-382.2]

Note: mtshan ma (= symbol or mark) in BC line (b) does not appear in AA. However, a corresponding word is found in the $A-y u$ wang jing 『阿育王経』（T 50. 135b2: 以塔印世 間 $=\underline{\text { mark }}$ the world by the stūpa). Therefore mtshan $m a$ is most likely not an addition of the Tibetan translator but goes back to a lost Sanskrit word. Dr. Mitsuyo Demoto suggested to restore an original wording stūpāmkaṃ (for stūpāinkam) of which only the akșara kam was omitted by inadvertency. The restored text can be translated as follows.

BC: $\mathrm{He}(=$ Aśoka $)$ who was the glory of the noble Maurya [dynasty] had made the whole world marked by stūpas for the benefit of the people. [Previously, he] obtained [the epithet of] "Aśoka the Fierce" on the earth, [but now, he has obtained the epithet of] "Aśoka the Righteous King" through that act.

AA: He (= Aśoka) who was the glory of the noble Maurya [dynasty] had made the whole world [marked by] stūpas for the benefit of the people. Previously, [he] obtained [the epithet of] "Aśoka the Fierce" on the earth, [but now, he has obtained the epithet of] "Aśoka the Righteous" through that act.

【Parallel verse 2】

(a) mngon du byas pa'i mchod rten bdun po de rnams las //

(b) drang srong de yi gdung rnams mau rya(rgya CD) des blangs nas //

(c) dpal ldan mchod rten ston ka'i sprin gyi 'od rnams kyi //

(d) stong phrag brgyad cur babs(bcas C) pa dus su zhag gis byas // [BC 28.65]

(A) tābhyas ${ }^{10)}$ saptabhyas ${ }^{11)}$ pūrvikābhyah krtibhyo

(B) dhātum ${ }^{(12 \cdots}$ tasya rșeh $^{\cdots 12)}$ sa hy upādāya mauryah ${ }^{13)} /$

(C) cakre stūpānām śāradābhraprabhānām ${ }^{14)}$

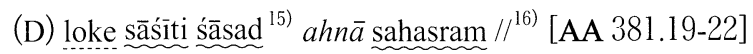

Note: It is necessary to correct mngon $\mathrm{du}$ (= actually or really) to sngon $\mathrm{du}$ (= previously) in BC line (a), according to pūrvikäbhyah (= previous) in AA line (A). Krti- (= structure) 
in AA line (A) might stand for mchod rten (= stūpa or caitya) in BC line (a). Stong phrag brgyad cu- in BC line (d) means 80,000, but it can hardly correspond to sāśiti ... sahasram in AA line (D). The usual number 84,000 is found in the Chinese translations ${ }^{17)}$ of both $\mathrm{BC}$ and $\mathrm{AA}$ but it is missing in Tibetan and Sanskrit texts of this verse. The meaning and function of babs pa in $\mathrm{BC}$ line (d) is not yet clear to me.

BC: The Maurya (= Aśoka) obtained relics of the R̦si (= Buddha) from those seven stūpas built in the past, and built in due course in a (single) day (?) 80,000 magnificent stupas that had the splendour of the clouds of autumn.

AA: The Maurya (= Aśoka) obtained relics of the Ṛsi (= Buddha) from those seven structures (= stūpas) [built] in the past. Ordering [it], he immediately built in the world 1,080(?) stūpas that had the splendour of the clouds of autumn.

\section{【Parallel verse 3】}
(a) dga' byed grong(greng $\mathrm{P}$ ) gnas mchod rten brgyad pa dang po ni //
(b) de yi dus su gus ldan klu rnams kyis bsrungs te /I
(c) de phyir gdung rnams thob pa ma yin rgyal po des //
(d) der byas pa la ma dad(dang NP) rgya chen gyur pa'o // [BC 28.66]
(A) rāmagrāme ${ }^{18)}$ tv aștamam stūpam adya
(B) nāgās tatkālam bhaktimanto rarakșuh 1
(C) dhātūny ${ }^{19)}$ etasmān nopalebhe sa rājā
(D) śraddhābhū ${ }^{20)}$ rājā cintayati yas tv atatkrtvā ${ }^{21)}$ jagāma // [AA 380.26-29]

Note: It is necessary to correct adya (=today) in AA line (A) to $\bar{a} d y a$ (= foremost) on the basis of dang po (= foremost) in BC line (a). Line (D) of AA is remarkably irregular metrically ${ }^{22)}$. Therefore the editors are anxious to make revisions (V: śraddhābhū(?) rājā cintayati yas tv etat kṛtvā jagāma //; M: śraddhālū rājā yas tv akṛtvā jagāma //). However, this problem can be solved with the help of BC. First, rāja cintayati $^{23)}$ (= king considers) can be deleted because it is missing in BC. Second, yas tv atatkrtvā should be corrected to yastvam tatkrtvā according to the footnote of $\mathrm{CN}$. Thus, line (D) can be read as follows: śraddhā bhüyastvam tatkrtvā jagāma. This phrase is similar with der byas pa la ... dad rgya 
( 78 ) Three Parallel Verses in the Buddhacarita and the Aśokāvadāna (К. Окамото)

chen gyur pa'o in BC line (d). However, I cannot make any suggestions about ma in BC line $(\mathrm{d})^{24)}$. But if this $m a$ is deleted, the passage can be translated as follows:

BC: At that time, pious Nāgas were protecting the eighth foremost stūpa that lay in the Rāma village. Therefore, the king did not obtain relics. After having done it (= having failed to obtain the relics (?)), [the king's] faith grew.

AA: At that time, however, pious Nāgas were protecting the eighth foremost stūpa in the Rāma village. Therefore, the king did not obtain relics. After having done it (= having failed to obtain the relics (?)), [the king's] faith grew.

As we have seen, these three verses correspond to each other largely. By comparing them, some of the difficulties in both texts can be solved. Moreover, we are able to recover the three Sanskrit verses of BC from the corresponding part of AA. Finally, we can find a closer relationship between $\mathrm{BC}$ and $\mathrm{AA}$ than it has generally been assumed by previous scholars.

《Abbreviation》 $\mathrm{AA}=$ Aśokāvadāna (page and line numbers are based on $\mathrm{CN}$ ). $\mathrm{BC}=$ Buddhacarita, Johnston ed., 1936, Lahore [New Enlarged reprint, Delhi, 1984]. CN = Divyāvadāna, Cowell and Neil ed., 1886, Cambridge [Reprinted 1987, Delhi]. V = Divyāvadānam, Vaidya ed., 1959, Darbhanga. $\mathbf{M}=$ Aśokāvadāna, Mukhopadhyaya ed., 1963, New Delhi. $\mathbf{C}=$ Cone ed. (Ge, 1-112b2). $\mathbf{D}=$ Derge ed. (Ge, 1-103b2). $\mathbf{N}=$ Narthang ed. ( $\mathrm{Ne}, 1-119 b 7) . \quad P=$ Peking ed. $(\dot{\mathrm{N} e}$, 1-124b8). $\mathrm{T}=$ The Taisho Shinshu Daizokyo, Tokyo.

《Note》 1) The Sanskrit text of BC is extant through the verse 31 of chapter 14 (with some lacunae). However, The work is thought to have originally consisted of 28 chapters, because the Chinese (Fo suo xing zan『仏所行讃』T. No. 192) and Tibetan translations (Sangs rgyas kyi spyod pa zhes bya ba'i snyan ngag chen po) both consist of 28 chapters. 2) In this article, Aśokāvadāna (= AA) stands for Chapters 26-29 in the Divyāvadāna. 3) Cf. Kensuke Okamoto 岡本 健資，「Divyāvadāna 第 27 章に見られる佛跡巡礼とBuddhacarita」(The Buddhacarita and the story of Aśoka's pilgrimage in Divyāvadāna, Chapter 27), 『東方学』(TŌHŌGAKU) 110, 2005, pp. 136-148. 4) A. Gawroński, Studies about the Sanskrit Buddhist Literature, Krakowie, 1919 , pp. 49-56. The parallel verse that has already been noted is as follows: tato nrpas tasya niśamya bhāvaṃ putrābhidhānasya manorathasya / snehasya lakṣmyā vayasaś ca yogyām ājñāpayām āsa vihārayātrām // [BC 3.3] $\fallingdotseq$ tato nṛpas tasya niśāmya bhāvaṃ putrābhidhānasya manorathasya / snehāc ca yogyaṃ manasā ca buddhvā ajñāpayām āsa vihāya yātrām // [AA 408.1-4] . BC 28.64 (C 11lb3-4: D 102b3-4: N 118b5-6: P 123b6-7) = AA (CN 381.26-382.2; V 241.7-10; M 55.11-14); BC 28.65 (C 11lb4: D 102b4-5: N 118b6-7: P 123b7-124al)=AA (CN 381.19-22; V 
Three Parallel Verses in the Buddhacarita and the Aśokāvadāna (K. Окамото) ( 79 )

241.1-4; M 55.4-7); BC 28.66 (C 11lb4-5: D 102b5: N 118b7-119al: P 124a1-2) = AA (CN 380.26-29; V 240.14-17; M 52.17-20). 6) I hereby mention only parallel verses. However, the two texts have a parallel passage that has not yet been noted (BC 14.45-46 [P 64b1-2; D 52b6-7] $\fallingdotseq$ AA 422.10-13). They are both about the suffering in the five gatis of samsāra.

āryo mauryaśrīh M. Obviously correct! $\quad$ 8) lokaś CN n. 7. $\quad$ 9) M: kṛtsne stūpān yạ̣ kārayāmāsa loke /. 10) tābhyaḥ V. 11) saptabhyạ̣ V. 12) tasyarșeh M. Obviously correct! 13) mauryaṃ CN n. 3. 14) śāradabhra- CN n. 4. 15) sāsad CN n. 5. 16) M: loke sāśíti hyahni cātuhsahasram //. 17） Fo suo xing zan『仏所行讃』 「開彼七王塔 以取於舍利 分布一旦起 八萬四千塔」(T 4.54b8-10); Za a han jing『雑阿含 経』「大王名阿育 於先八塔中 各取其舍利 於此閻浮提 建立諸佛塔 八萬及四千 縱 廣殊妙勝 一日都使畢」(T 2. 165b6-9); A-yu wang jing『阿育王経』「於先七塔中 取世尊舍 利 我孔雀姓王 一日中造作 八萬四千塔 光明如白雲」(T 50. 135a25-27). 18) 'sti M. 19) dhātūn M. 20) Speyer points out that śraddhābhū should be corrected to śraddhālū (J. S. Speyer, Critical Remarks on the Text of the Divyāvadāna, Wiener Zeitschrift für die Kunde des Morgenlandes, Band XVI, 1902, p. 348). 21) yastvaṃ tatkṛtvā (mss. ABD); yastvatatkṛtvā (ms. C) CN n. 5. 22) The meter of these three parallel verses is Vaiśvadevī.

23） This rājā cintayati in AA line (D) appears in the A-yu wang jing『阿育王経』「時王思惟此 塔第一. 是故龍王倍加守護. 我於是塔不得舎利. 思惟既竟還其本國.」(T 50. 135a9-11).

24) There is a text recording the king's acquisition of relics from the stūpa of the Nāga (see the $Z a$ a han jing『雑阿含経』T 2. 165al7-18, 21-22). Therefore, we should be careful about correcting the text to der ma byas pa la.

* I would like to express my gratitude to Professor Katsumi Mimaki and Professor Kiyoshi Okano for their kind suggestions. After my completing this article, Professor Michael Hahn and Dr. Mitsuyo Demoto gave some important suggestions. Moreover they suggested to emend tat krtvā jagāma [this is not a compound, $\mathrm{MH}$ ] (in the parallel verse 3) as tatkrte 'syājagāma. They gava more suggestions, but I was not able to reflect those suggestions this time enough. I apologize to them at this point and I'd like to express my gratitude to them.

〈Key Words〉 Buddhacarita, Aśokāvadāna, Divyāvadāna, Aśvaghoṣa, Aśoka

(Part-time Lecturer, Ryūkoku University, Ph.D.) 